\title{
ORGANIZATIONAL FORGETTING PART I: \\ A REVIEW OF THE LITERATURE AND FUTURE RESEARCH DIRECTIONS
}

\begin{tabular}{|r|l|}
\hline Journal: & The Learning Organization \\
\hline Manuscript ID & TLO-12-2019-0182 \\
\hline Manuscript Type: & Article \\
\hline Keywords: & $\begin{array}{l}\text { Organizational Forgetting, knowledge loss, knowledge depreciation, } \\
\text { unlearning, organizational knowledge }\end{array}$ \\
\hline
\end{tabular}

\section{SCHOLARONE ${ }^{\text {M }}$ \\ Manuscripts}

Accepted manuscript of:

Mariano, S., Casey, A. and Olivera, F. (2020), "Organizational forgetting Part I: a review of the literature and future research directions", The Learning Organization, Vol. ahead-of-print No. ahead-of-print.

https://doi.org/10.1108/TLO-12-2019-0182 
Running head: ORGANIZATIONAL FORGETTING

\title{
ORGANIZATIONAL FORGETTING PART I:
}

\section{A REVIEW OF THE LITERATURE AND FUTURE RESEARCH DIRECTIONS}

\begin{abstract}
Purpose: The purpose of this two-part paper is to systematically review and synthesize the literature on organizational forgetting.

Design/methodology/approach: A systematic literature review approach was used to synthesize current theoretical and empirical studies on organizational forgetting.

Findings: The review and synthesis of the literature revealed that (1) the organizational forgetting literature is fragmented, with studies conducted across disparate fields and using different methodologies; (2) two primary modes (i.e., accidental and purposeful) and three foci (i.e., knowledge depreciation, knowledge loss, and unlearning) define current organizational forgetting literature; and (3) the factors that influence organizational forgetting can be grouped into four clusters related to individuals, processes, tools, and organizational context.

Research limitations: This literature review has limitations related to time span coverage and journal article accessibility.

Originality/value: This paper offers an integrative view of organizational forgetting that proposes a holistic and multilevel research approach and systematic synthesis of organizational forgetting research.
\end{abstract}

Article classification: Literature review 


\section{INTRODUCTION}

In an age of disruption, an aging workforce, and increased emphasis on big data analytics, managing organizational knowledge becomes crucial. Effective knowledge management involves capturing, retaining, and transferring valuable lessons from past experiences as well as quickly discarding practices that have become obsolete or irrelevant to organizational purposes (Argote and Miron-Spektor, 2011; Becker, 2010, 2018a, 2018b; Massingham, 2008). These activities are especially important because of rapid technological advancements that require agile organizational responses (Blackler et al., 1999); the disruptions caused by turnover of an entire generation retiring from the workforce (Bratianu and Leon, 2015; Joe et al., 2013; Calo, 2008); and the challenges of knowledge retention when organizations have access to vast amounts of data and information and sophisticated data analysis tools (George et al., 2014). Given the relevance of such challenges, it is not surprising that scholars are increasingly interested in the study of organizational forgetting from theoretical and empirical standpoints.

This two-part review provides a systematic analysis and synthesis of this organizational forgetting literature and suggests a research agenda to enhance our understanding of organizational forgetting. The field has followed three different, albeit related, lines of inquiry: knowledge depreciation (e.g., Argote et al., 1990), knowledge loss (e.g., Daghfous et al., 2013), and unlearning (Hedberg, 1981). These lines of inquiry—which have evolved mostly independently but have addressed fundamental aspects of organizational forgetting —are the focus of our review, which adds to some recent syntheses focusing on unlearning and forgetting (Klammer and Gueldenberg, 2019a) and intentional forgetting (Kluge and Gronau, 2018), as well as organizational forgetting empirical work (Kluge et al., 2019). 
Our synthesis of the literature revealed that current organizational forgetting work is fragmented, with studies conducted across disparate fields and using different methodologies. Two primary modes (i.e., accidental and purposeful) and three foci (i.e., knowledge depreciation, knowledge loss, and unlearning) define current organizational forgetting literature. Four clusters of factors related to individuals, processes, tools, and organizational context influence organizational forgetting.

This Part I review is organized as follows. First, we explain our review methodology (Suddaby, 2010; Tranfield et al., 2003; Webster and Watson, 2002). Second, we define organizational forgetting and present a chronological distribution of the articles included in this review. Third, we present a literature-driven organizing framework. We close with conclusions.

\section{METHODOLOGY}

To identify publications about organizational forgetting, we followed the process recommended by Tranfield et al. (2003) and Webster and Watson (2002) and conducted a systematic literature review of work published in 48 journals between 1970 and 2018, adding more recent articles that appeared in 2019 (i.e., Klammer and Gueldenberg, 2019a, 2019b; Cutcher et al., 2019; Levallet and Chan, 2019). We followed three basic steps to assess current contributions: planning, conducting, and reporting (Tranfield et al., 2003). An overview of the process and results is offered in Table 1, Table 2, and Figure 1.

Insert Tables 1 and 2 and Figure 1 about here 


\section{ORGANIZATIONAL FORGETTING LITERATURE STATUS OF KNOWLEDGE}

\section{Definitions}

We take as a point of departure the conceptualization of organizational forgetting provided by Martin de Holan and Phillips (2004b). They defined organizational forgetting as "the loss, voluntary or otherwise, of organizational knowledge" (2004b: 1606). We found this definition appropriate for the purpose of this review because, although recently confronted (Hatch and Schultz, 2017; Foroughi and Al-Amoudi, 2019), it has been used widely in the literature, incorporates the role of agency (i.e., purposeful forgetting), and encompasses a set of foci that reflects the key domains of study in the literature, that is, knowledge depreciation, knowledge loss, and unlearning.

Employing this conceptualization in our systematic analysis and synthesis of the organizational forgetting literature helped us assess the development in the field of the four proposed modes of organizational forgetting — dissipation, degradation, suspension, and purging - to see whether or not this taxonomy contributed to a concrete advancement in current understanding. It also helped us form an impression of the role of agency in purposeful organizational forgetting studies with specific reference to the contribution of key individuals' cognition and behaviors. Finally, it helped us understand the extent to which distinguishing between newly acquired knowledge and knowledge already existing in organizations possessed strong theoretical value for the study of knowledge depreciation, knowledge loss, and unlearning. From this assessment, we were able to identify the use of the two primary modes of forgetting (i.e., accidental and purposeful) and distinguish three foci (i.e., knowledge depreciation, knowledge loss, and unlearning) that, as a whole, define current organizational forgetting literature, as described in the following sections. 


\section{Chronological Development of the Three Fields of Study}

The topic of "knowledge depreciation" was studied primarily in research on learning curves that started appearing in the 1950s and developed in the 1970s (e.g., Baloff, 1970), 1980s (e.g., Smunt, 1987; Sule, 1983), and 1990s (e.g., Darr et al., 1995; Epple et al., 1991; Argote et al., 1990), with one of the first papers published in the economics literature to discuss how production interruptions had a negative effect on learning curves (Hirsch, 1952). This literature on knowledge depreciation referred to unintentional and gradual knowledge decay in production settings that could be empirically calculated through estimated models (e.g., Thompson, 2007; Benkard, 2000; Argote et al., 1990). Almost the entire set of articles we reviewed ( $\mathrm{N}=18)$ were empirical ( $n=17)$, mostly quantitative $(n=14)$, with a few exceptions including two experiments and one mixed-methods study. These articles were predominantly published in the economics $(n=3)$, operation research $(n=4)$, and management science literature $(n=5)$, with a few studies published in general and human resources management journals $(n=3)$, organization studies journals $(n=2)$, or as book chapters $(n=1)$. Human capital theory $(n=2)$ and learning curve theory $(n=14)$ dominated the theoretical perspectives of these studies, with a few exceptions focusing on organizational memory or organizational routines $(n=2)$. Contrasting findings emerged regarding depreciation rates and why depreciation occurs in organizations.

The term "knowledge loss" has been used since the 2000s (e.g., Eckardt et al., 2014; Schmitt et al., 2011; Treleaven and Sykes, 2005) to describe the accidental disappearance of existing organizational knowledge. Knowledge loss appeared to depend on retention failures and, compared to knowledge depreciation, occurred more immediately. Researchers who studied knowledge loss did not use estimated models compared to those who studied knowledge depreciation, and they often used the two terms interchangeably (e.g., Daghfous et al., 2013; 
Cattani et al., 2012). Similarly to the knowledge depreciation literature, contributions to the knowledge loss literature $(\mathrm{N}=40)$ were mostly empirical $(\mathrm{n}=32)$, although qualitative studies were predominant $(n=20)$ compared to quantitative $(n=6)$ or mixed-methodology studies $(n=6)$. Conceptual contributions also started appearing $(n=8)$, mostly during the 2000 s decade. Knowledge loss articles were predominantly published in general management $(n=10)$, management development $(n=4)$, organization studies $(n=17)$, and strategy journals $(n=6)$, with the exception of one key article published in the management science literature (i.e., Martin de Holan and Phillips, 2004b) and two book chapters that both took an activity theory perspective on knowledge loss (Blackler et al., 1999; Engeström et al., 1990). Additional theories employed widely in this literature included the knowledge-based view of the firm $(n=12)$, organizational learning theory $(n=6)$, and human capital theory $(n=4)$, along with a few other theories such as organizational memory, organizational identity, transaction cost theory, practice-based theory, critical realism, and social network theory.

Finally, the term "unlearning" refers to the purposeful removal of existing organizational knowledge, although clarification and alignment of terminology are still needed (Becker, 2019). The first use of the term was traced to the work of Dewey published in 1938 (see Nguyen, 2017), and the concept has since followed the popular theorizing by Hedberg (1981) on how organizations learn and unlearn. Unlearning research developed increasingly in the last 15 years (e.g., Volland, 2019; Klammer et al., 2019; Fiol and O’Connor, 2017a, 2017b; Gutierrez et al., 2015; Martin de Holan, 2011; Becker, 2010). In contrast to the knowledge depreciation and loss literature, contributions to the unlearning literature $(\mathrm{N}=53)$ were mostly conceptual $(\mathrm{n}=27)$. Empirical contributions also appeared in the literature, especially in more recent years $(n=26)$, with a predominance of qualitative studies $(n=14)$; a stronger underpinning of empirical research 
on unlearning is needed (Becker, 2019; Kluge et al., 2019). Interestingly, articles were quite scattered across a variety of fields, including general management $(n=17)$, human resource management $(n=2)$, information management $(n=2)$, innovation $(n=3)$, management development $(n=3)$, marketing $(n=1)$, technology management $(n=1)$, organization studies $(n=15)$, strategy $(n=4)$, or as book chapters $(n=5)$.

Unlearning studies made extensive use of learning theories $(n=14)$, along with behavioral strategy or agency theories $(n=8)$. Additional theoretical perspectives included the resourcebased view and knowledge-based view of the firm, organizational memory, institutional theory, and dynamic capabilities theory. Most of this literature discussed unlearning in the context of organizational learning and change and focused on the role of managerial cognition and actions (e.g., Gutierrez et al., 2015; Martin de Holan, 2011; Akgün et al., 2007; Sinkula, 2002; Barker et al., 2001; Mezias et al., 2001) and on political issues (e.g., Coopey and Burgoyne, 2000; Cutcher et al., 2019; Foroughi and Al-Amoudi, 2019) related to unlearning. Several studies also pointed out the role of environmental conditions in unlearning (e.g., Leal-Rodriguez et al., 2015; Cegarra-Navarro et al., 2012). Of note is the ongoing debate on what it means to unlearn and whether unlearning exists (e.g., Tsang, 2017; Howells and Scholderer, 2016).

Table 3 provides a chronological synthesis of the literature in these three areas.

Insert Table 3 about here

\section{LITERATURE-DRIVEN ORGANIZING FRAMEWORK}

\section{AND KEY RESEARCH STUDIES}

After we reviewed and categorized the literature chronologically, we followed an inductive theorizing process (Tranfield et al., 2003) to organize key research studies into a 
literature-driven framework that would capture the modes, foci, and factors influencing organizational forgetting. This inductive theorizing process involved several iterative phases of data reduction, display, and conclusion drawing/verification (Miles and Huberman, 1994) and included a certain degree of flexibility, active interrogation of data, and constant comparison (Strauss and Corbin, 1998). Through this inductive theorizing, we identified two modes (i.e., accidental and purposeful) and three foci (i.e., knowledge depreciation, knowledge loss, and unlearning) of organizational forgetting. We were also able to synthesize the factors influencing organizational forgetting that met the requirements of recurrence, repetition, and forcefulness and emerged in an iterative way (Owen, 1984), forming four clusters related to individuals, processes, tools, and organizational context. As a whole, these clusters define current understanding of the factors influencing organizational forgetting and constitute the objects of discussion in existing theoretical and empirical studies.

Figure 2 represents visually the modes, foci, and factors that influence organizational forgetting. In the next sections we present findings grouped into the four clusters of individuals, processes, tools, and organizational context and discuss related literature on knowledge depreciation, knowledge loss, and unlearning.

Insert Figure 2 about here

\section{Individuals: Turnover and Managerial Agency}

Most studies have addressed organizational forgetting in relation to individuals who belong to or lead organizations, discussing the role of turnover and managerial agency as potential factors influencing organizational forgetting. 
Turnover. Turnover is defined as the departure or movement of organizational members. A large stream of research $(n=7,41 \%)$ in the accidental forgetting literature focused on the role of turnover, discussing its detrimental effect on organizational performance and change.

Although a definite link between turnover and depreciation rate has not yet been made in the knowledge depreciation literature, there is a tendency to attribute fast knowledge depreciation to high turnover rates, with some exceptions. Turnover seemed to drive knowledge depreciation in manufacturing settings such as aircraft production (Benkard, 2000) and food processing (Lopez and Sune, 2013), where workers embodied production experience and knowledge. However, this effect did not seem to hold in shipbuilding manufacturers (Argote et al., 1990; Thompson, 2007), where other factors such as transfer mechanisms or changes in the product mix were proposed to better explain depreciation rates. Similarly, in the service industry, studies of pizza franchises (Darr et al., 1995) and ambulance companies (David and Brachet, 2011) appeared to connect depreciation to turnover. This last finding seems to confirm the hypothesis that organizations with skilled workers are more affected by depreciation in the presence of high turnover rates (Argote, 2013).

In the knowledge loss literature, researchers investigated how turnover influenced organizational knowledge and what consequences it had on organizational memory and decision making. The focus of this stream of literature $(n=25,66 \%)$ was on the characteristics of members leaving the organization, supporting the hypothesis that turnover might have a higher or lower influence on knowledge loss depending on who departs and what personal and relational knowledge leaves with them. For instance, turnover was found to increase costs and inefficiencies and to lead to loss of relationships among members, as discovered by Shaw, Duffy, Johnson, and Lockhart (2005) in a study conducted in 38 locations of a restaurant chain. This 
study found a curvilinear relationship between losses of social capital and store performance, with turnover moderating this relationship, where the parting of those who held communication relationships was found to be less detrimental than the parting of those who held structural roles. A direct relationship between turnover-induced broken links in social networks and knowledge loss was also proposed by Droege and Hoobler (2003) and by Feldman and Feldman (2006), who discussed the role of lost socially embedded relationships in organizational forgetting from network and practice perspectives.

In general, researchers focused on the aging workforce (Massingham, 2018; Bratianu and Leon, 2015; Calo, 2008), retiring employees (Levy, 2011), departure of senior members (Joe et al., 2013), or employee downsizing (Miller et al., 2012; Schmitt et al., 2011; Ward and Wooler, 2010). The performance level of departing employees (Price, 1977; Dalton et al., 1981; Dreher, 1982; Jacovsky, 1984; Wells and Muchinsky, 1985; McEvoy and Cascio, 1987; Sumbal et al., 2018) and role or position of departing members (Parise et al., 2006; see also Mowday et al., 1982) were proposed to have more influence on knowledge loss, especially if the departing individuals belonged to top management teams (Carty and Walsh, 2007; Ciuk and Kostera, 2010), championed routines (Easterby-Smith and Lyles, 2011), had gatekeeper (Allen, 1977) or peripheral positions (Parise et al., 2006), represented organizational brokers (Parise et al., 2006), or acted as central nodes in networks (Shaw et al., 2005).

Although there is general consensus on the harmful influence of turnover on knowledge loss, some studies found that turnover is not as detrimental at times. Examples of this include two case studies of organizational memory, one by Casey (1997) of a multisite nonprofit with high turnover of younger and less skilled employees and one by Scalzo (2006) of the operations division of a mid-sized financial services organization. These studies found little or no impact of 
turnover on the organization's memory system, although a significant amount of individuals and related knowledge left the observed organization. In the latter (Scalzo, 2006), the outcome was explained by actions, such as planning for change and automation, that were taken by the observed organization in due time during restructuring. In the former (Casey, 1997), the minimal impact on the memory system was attributed to the organization's mission and identity. Certain forms of collaborations or structure are often proposed to ease the disruptive effects of turnover due to employee downsizing (Schmitt et al., 2011). Researchers also proposed methods to calculate the risks associated with personnel departures (Jafari et al., 2011; Jennex, 2014).

Managerial agency. Managerial agency refers to managerial cognition and discretion. Managerial agency was investigated extensively in the organizational forgetting literature, predominantly in the study of unlearning $(n=17,39 \%)$, with a few exceptions that appeared in the knowledge depreciation $(n=2,12 \%)$ and knowledge loss literature $(n=5,14 \%)$. A common characteristic of this literature was the presence of contrasting and often contradicting views on whether managerial agency contributed to or prevented knowledge depreciation and loss and whether it facilitated or inhibited unlearning. These contradictions started appearing in a few examples in the knowledge depreciation (e.g., Kleiner et al., 2012; Baloff, 1970) and loss literature (e.g., Treleaven and Sykes, 2005; Fernandez and Sune, 2009; Mariano and Casey, 2013, 2016) but developed consistently in the unlearning literature (Mariano et al., 2018).

Some studies highlighted the critical role of managers in discarding bad practices and facilitating unlearning (Gutierrez et al., 2015; Martin de Holan et al., 2004a; Zhao et al., 2013; Klammer et al., 2019). This work discussed the role of managers in planning or supporting continuous unlearning processes such as exploiting new opportunities, experimenting, and listening to dissent (Nystrom and Starbuck, 1984); proposed critical steps to help employees 
unlearn, i.e., creating situational awareness, providing islands of temporal and spatial freedom, encouraging an error-forgiving and stop-doing culture, and reducing the influence of old knowledge over time (Klammer et al., 2019); and supported the promotion of an unlearning context that encouraged reflection on and analysis of events (Cegarra-Navarro and Dewhurst, 2006; Cegarra-Navarro et al., 2012) and guided organizational change (Klein, 1989) and innovation (Leal-Rodriguez et al., 2015).

Other studies focused on the possible negative influence of managers' old logics (Sinkula, 2002) or mental models and worldviews that trapped organizations in old beliefs and schemes (Akgün et al., 2007). This research stream argued that unreliable current beliefs and perceptual errors and self-deceptions of senior managers obstructed organizational change (Starbuck, 1996). For example, Akgün et al.’s (2007) study of the Polaroid Corporation, originally investigated by Tripsas and Gavetti (2000), discussed how managerial beliefs prevented unlearning and delayed the development and commercialization of digital cameras. Consistent with this conclusion, Fernandez and Sune (2009), Carlsson (1991), Nystrom and Starbuck (1984), Pratt and Barnett (1997), and Starbuck (1996) argued that old beliefs and perceptions, blind and rigid ideas, rigid conceptual frames of reference, obsolete or misleading knowledge, and outdated mental models interfered with adaptation to changing environments. This adaptation was also proposed to connect to political issues and to the managerial power and privilege to control organizational memory usage and structure (Casey and Olivera, 2011; for empirical work on power and politics see also Volland, 2019; Cutcher et al., 2019; Foroughi and Al-Amoudi, 2019) and to keep in place existing practices and routines considered more secure and legitimate (Tsang and Zahra, 2008) or disband ideas that might not be in favor by the dominant political group (Easterby-Smith and Lyles, 2011), as proposed by Mena et al. (2015) in 
their work on manipulations of events that, over time, could undermine the collective mnemonic traces of past events.

Some researchers explored how to overcome the challenges posed by managerial agency. A proposed solution was to remove top managers, a strategy confirmed by empirical studies of Eastern European joint ventures (Markóczy, 1994). Fernandez and Sune (2009), Barker et al. (2001), and Nystrom and Starbuck (1984) also suggested changing cognitive structures through actions such as replacing top managers as a group to enable strategic orientation (Mezias et al., 2001), especially during periods of crisis (Antonacopoulou and Sheaffer, 2013; Nystrom and Starbuck, 1984). Sinkula (2002) proposed "exorcism” (i.e., removal of people) during crises as a faster unlearning alternative to "extinction" (i.e., removal of past knowledge). CEO turnover and top management team heterogeneity were proposed to increase the likelihood of reorientation and, as a consequence, promote unlearning (Lant et al., 1992). Other researchers, however, expressed serious disagreement about these strategies, pointing out the uncertainty that followed the departure of members from top management teams (Gaur et al., 2011) and claiming that managerial practices could be unlearned and replaced by learning capabilities that were facilitated by nonthreatening environments to enable improved behaviors, collaboration, incremental orientation (i.e., acknowledgment of errors), induction (e.g., "broad lessons"), purpose, and symbolism (Klein, 1989) and by an open form of politics that triggered unlearning because it questioned performance and promoted new alternatives and experimentation (Coopey and Burgoyne, 2000). 


\section{Processes and Tools}

Production mechanisms, behavioral changes, and changes in physical or electronic repositories were identified as potential factors influencing organizational forgetting in the cluster of organizational processes and tools.

Processes: Production mechanisms. Production mechanisms refer to size, phases, mixes, and frequency of operational routines. At the level of processes, production mechanisms as factors influencing organizational forgetting were predominantly discussed in studies of knowledge depreciation $(n=11,65 \%)$. These studies focused on experience-based knowledge and learning mechanisms that held organizational processes and routines and highlighted the disruptive effects of knowledge depreciation. A study conducted in the pharmaceutical industry, for instance, provided evidence that operational routines that guided production had a tendency to decay over time (Anand et al., 2012). On a similar note, a group of studies investigating shipbuilding (Argote et al., 1990) and aircraft production (Benkard, 2000) provided evidence of depreciation of experience-based knowledge over time, showing how knowledge acquired in the past had less effect on organizational routines and performance than more recently acquired knowledge. Lot size and frequency of production (Hirsch, 1952), as well as phases of production (Smunt, 1987; Sule, 1983), production mix changes (Thompson, 2007), scope of task (David and Brachet, 2011), and internal disruptions in production (Anderson and Lewis, 2013) were also proposed to determine depreciation of organizational knowledge and routines. Similarly, product or process obsolescence was proposed to produce depreciation (Argote, 2013), especially from one production to another, as also shown by Benkard (2000) in the analysis of two versions of the L-1011 aircraft production where the aircraft's second model only partially benefited from production experience acquired from work on the first model. 
Processes: Behavioral changes. Behavioral changes refer to the acts of discarding obsolete knowledge or inappropriate knowledge structures to foster new behavior. Most of the work on behavioral changes was published in the unlearning literature $(n=12,29 \%)$. Hedberg (1981) was the first to theorize the link between learning and unlearning, where unlearning old behavior was proposed to precede the learning of new behavior. This view was reinforced by subsequent theoretical (Tsang, 2017; Tsang and Zahra, 2008) and empirical studies (Tsang, 2008), with a few exceptions questioning unlearning (Howells and Scholderer, 2016).

Conceptualizations of strategic problem formulation, for instance, proposed that during reorientation periods, unlearning was vital because contextual discontinuities triggered secondorder learning and involved changes in decision-making premises and assumptions, requiring unlearning of prior modes of organizing such as practices and routines and increasing behavioral variability (Lyles and Thomas, 1988). This view was confirmed by studies of contractor organizations in Hong Kong that found a correlation between unlearning and double-loop learning (Argyris and Schön, 1978) to help change previous assumptions, beliefs, and routines that had caused errors and to support subsequent learning processes (Wong et al., 2012).

On a similar note, studies of small and medium construction companies in Spain found the importance of discarding obsolete knowledge and inappropriate knowledge structures to foster new behavior, especially in relation to improved customer relations (Cegarra-Navarro et al., 2012). In both examples, these organizations took advantage of learning from experience which, in turn, challenged and modified existing routines, practices, and behaviors and capitalized on learning from errors or opportunities raised by mistakes (Argyris, 1976).

Usually, management researchers proposed that when reconfigurations happened, they led to transition periods with higher costs in the short term before new ways of working were 
learned efficiently (Bridoux et al., 2013; see also Klammer and Gueldenberg, 2019b). This transition period was proposed to build upon three connected processes of initial routine destabilization: ongoing discarding-from-use of old behaviors; experimenting with new behaviors; and discharge of prior understanding to develop new understanding (Fiol and O'Connor, 2017a, 2017b). Research also proposed that temporal and spatial freedom could help identify outdated knowledge and facilitate unlearning practices (Klammer and Gueldenberg, 2019b).

Tools: Decay or loss of physical and electronic repositories. Tools refer to physical or electronic repositories as knowledge storage facilities. They are mainly discussed in studies of knowledge depreciation $(\mathrm{n}=4,23 \%)$ and $\operatorname{loss}(\mathrm{n}=5,14 \%)$. Although there is a general consensus on the positive role of tools to retain organizational knowledge and prevent forgetting, concerns still exist if accidental decay or loss of repositories occurs, disrupting existing stored knowledge.

Those who propose a positive influence of tools on knowledge depreciation discussed how a shared database to store electronic copies of past designs contributed, together with low turnover rate, acquaintance of workers, and small organization size, to almost eliminating depreciation in an architectural engineering company, reporting a rate of only $0.2 \%$ decay from one month to another (Boone et al., 2008). Similarly, quality improvement initiatives embedded in technology were found to exhibit lower depreciation rates compared with knowledge embedded in routines or individuals, as shown in a study of a large automotive manufacturer (Agrawal and Muthulingam, 2015); and knowledge acquired through learning-by-doing that was embodied in technology was proposed to ensure complete transfer of knowledge across shifts, as reported in a study of a North American trunk plant producing a single vehicle (Epple et al., 1991). These findings seem to confirm that knowledge embedded in tools is less prone to 
depreciation than knowledge embedded in routines or organizational members, a research hypothesis also discussed in studies of turnover-induced forgetting. Consequently, organizations with a lower level of technology could be affected by depreciation more than technologically sophisticated organizations (Argote, 2013).

Research also proposed that when organizational repositories decayed due to the passage of time, knowledge was likely to depreciate, as reported by Argote (2013) in the cases of the Steinway piano company (Lenehan, 1982) and the "Star Wars" trilogy (Morgenstern, 1997). In the first case, organizational records (blueprints) were lost or became difficult to access. In the second case, film exhibited physical deterioration due to the passage of time. In both cases, the conclusion was that "organizational knowledge can exhibit decay: Having knowledge at one point in time does not guarantee that the organization will have it in the future" (Argote, 2013: 72).

On a similar note, in the knowledge loss literature, researchers investigated the disruptive effects of losing storage facilities, records, or databases and discussed how these structures could become difficult to access due to technical or physical constraints (Easterby-Smith and Lyles, 2011). For instance, the study conducted by Blackler, Crump, and McDonald (1999) in an organization designing and producing high-technology electro-optics products found that a large part of documents related to previous work became inaccessible due to a "clear desk policy" that was introduced after the opening of a new factory. Similarly, the work of Fernandez and Sune (2009) proposed that losing a repository had a negative effect on organizational memory, especially if the repository was highly centralized.

These studies were similar in that the structures were considered retention facilities of codified knowledge that were proposed to reduce knowledge loss, as also discussed by Levy 
(2011), who considered the act of documenting a successful strategy of knowledge retention.

However, this view was not supported by studies conducted in multiple manufacturing and service firms that pointed out how relying solely on standard operating procedures, information systems, or codification of knowledge in databases could undermine knowledge retention and lead to knowledge loss (Daghfous et al., 2013).

\section{Organizational Context: Structure}

The organizational context played a key role in organizational forgetting studies, where it was proposed that, together with time, the space where organizational members operated had a direct impact on learning and forgetting - i.e., "the impact of forgetting on organizations is contingent on its context" (Martin de Holan and Phillips, 2004a: 425). In the current organizational forgetting literature, research has discussed the contribution of structure to organizational forgetting.

Structure. Structure refers to the organizational size, infrastructures, and level of bureaucratization. In the knowledge loss literature, the contribution of organizational structure to organizational forgetting ( $\mathrm{n}=4,11 \%)$ was discussed by Daghfous et al. (2013), who suggested that infrastructure capabilities and strategic coordination among organizational units led to knowledge loss if they were not properly developed, since knowledge was proposed to reside in units (i.e., individuals, groups, organization) and their relationships. The study of Carmona and Gronlud (1998) in two large automobile manufacturers in Spain and Sweden reached similar conclusions, proposing that organizational structure drove organizational forgetting and influenced the success or failure of innovative projects due to hierarchy pressure, resource constraints, and lack of teams' formal recognition, which caused more difficulties in carrying out proper learning. 
The role of structure and culture was extensively discussed in empirical studies taking a cultural historical activity theory perspective (Blackler et al., 1999; Engeström et al., 1990). These studies suggested analyzing collective learning and forgetting in terms of the cultural and organizational infrastructure that a community used and the related activities that its members enacted. According to this perspective, organizational forgetting occurred through the disintegration or fall into disuse of the community's collective infrastructure for learning or because of the disassociation and disorientation of members. Communities, dialogue, (re)engagement, and (re)orientation were proposed to mitigate knowledge loss in these studies. Similarly, collective forgetting was proposed to manifest when once-useful memories lost their practical usefulness or the past became uprooted due to changes beyond recognition of social relations and memories (Foroughi and Al-Amoudi, 2019).

In the unlearning literature $(n=9,22 \%)$, research proposed that organizational size influenced unlearning and consequent performance, showing that increased bureaucratization interfered with learning from mistakes (Daneke, 1985), made it more difficult to unlearn larger amounts of existing knowledge (Casillas et al., 2010), and provided less opportunity for unlearning to innovate (Leal-Rodriguez et al., 2015) or implement strategic change (Mezias et al., 2001). Downsizing in response to environmental changes was suggested to facilitate organizational change and adaptation (Miller et al., 2012), together with startups (Barkema and Vermeulen, 1998), spinouts (Cirillo et al., 2014), or spinoffs (Ito and Rose, 1994) that provided a clean slate and facilitated unlearning through the separation of business units. Additionally, changes to hierarchical structure were proposed to influence the formation of an informationseeking culture and participative learning systems that promoted unlearning (Carlsson, 1991). 


\section{CONCLUSION}

Although no unified theories of organizational forgetting emerged, in this systematic literature review we identified key research studies that reflect how knowledge depreciation, knowledge loss, and unlearning were conceptualized and discussed in the organizational forgetting literature over the past half century. Taken as a whole, these research studies allowed us to identify current influencing factors and criticalities related to organizational forgetting and its several unexplored areas.

\section{REFERENCES}

Agrawal, A. and Muthulingam, S. (2015), "Does organizational forgetting affect vendor quality performance? An empirical investigation", Manufacturing and Service Operations Management, Vol. 17 No. 3, pp. 350-367.

Akgün, A.E., Byrne, J.C., Lynn, G.S. and Keskin, H. (2007), “Organizational unlearning as changes in beliefs and routines in organizations", Journal of Organizational Change Management, Vol. 20 No. 6, pp. 794-812.

Allen, T. J. (1977), Managing the Flow of Technology: Technology Transfer and the Dissemination of Technological Information within the R\&D Organization, MIT Press, Boston, MA.

Anand, G., Gray, J.V. and Siemsen, E. (2012), “Decay, shock, and renewal: Operational routines and process entropy in the pharmaceutical industry”, Organization Science, Vol. 23 No. 6, pp. 1700-1716.

Anderson, E.G. and Lewis, K. (2013), “A dynamic model of individual and collective learning amid disruption”, Organization Science, Vol. 25 No. 2, pp. 356-376. 
Antonacopoulou, E.P. and Sheaffer, Z. (2013), "Learning in crisis: Rethinking the relationship between organizational learning and crisis management", Journal of Management Inquiry, Vol. 23 No. 1, pp. 5-21.

Argote, L. (2013), Organizational Learning: Creating, Retaining and Transferring Knowledge, Springer, New York, NY.

Argote, L., Beckman, S.L. and Epple, D. (1990), “The persistence and transfer of learning in industrial settings", Management Science, Vol. 36 No. 22, pp. 140-154.

Argote, L. and Epple, D. (1990), "Learning curves in manufacturing”, Science, Vol. 247, pp. $920-924$.

Argote, L. and Miron-Spektor, E. (2011), “Organizational learning: From experience to knowledge", Organization Science, Vol. 22 No. 5, pp. 1123-1137.

Argyris, C. (1976), "Single-loop and double-loop models in research on decision making”, Administrative Science Quarterly, Vol. 21, pp. 363-375.

Argyris, C. and Schön, D. (1978), Organizational Learning: A Theory of Action Perspective, Addison-Wesley, Reading, MA.

Bailey, C.D. (1989), "Forgetting and the learning curve: A laboratory study", Management Science, Vol. 35 No. 3, pp. 340-352.

Baloff, N. (1970), “Startup management”, IEEE Transactions, Vol. 17 No. 4, pp. 132-141.

Barkema, H.G. and Vermeulen, F. (1998), “International expansion through start-up or acquisition: A learning perspective", Academy of Management Journal, Vol. 41 No.1, pp. 7-26.

Barker, V.L., III, Patterson, P.W., Jr. and Mueller, G.C. (2001), “Organizational causes and strategic consequences of the extent of top management team replacement during turnaround attempts", Journal of Management Studies, Vol. 38 No. 2, pp. 235-269. 
Becker, K. (2010), "Facilitating unlearning during implementation of new technology”, Journal of Organizational Change Management, Vol. 23 No. 3, pp. 251-268.

Becker, K. (2018a), "Knowledge management and unlearning/forgetting”, in Syed, J., Murray, P., Hislop, D. and Mouzughi, Y (Eds.), The Palgrave Handbook of Knowledge Management, Palgrave Macmillan, Cham, Switzerland.

Becker, K. (2018b), “Organizational unlearning: Time to expand our horizons?” The Learning Organization, Vol. 25 No. 3, pp. 180-189.

Becker, K. (2019), “Organizational unlearning: The challenges of a developing phenomenon”, The Learning Organization, in press. https://doi.org/10.1108/TLO-05-2019-0082.

Benkard, C.L. (2000), “Learning and forgetting: The dynamics of aircraft production”, American Economic Review, Vol. 90 No. 4, pp. 1034-1054.

Blackler, F., Crump, N. and McDonald, S. (1999), “Organizational learning and organizational forgetting: Lessons from a high technology company”, in Easterby-Smith, M., Araujo, L. and Burgoyne, J. (Eds.), Organizational Learning and the Learning Organization: Developments in Theory and Practice, Sage, Thousand Oaks, CA, pp. 194-216.

Boone, T., Ganeshan, R. and Hicks, R.L. (2008), "Learning and knowledge depreciation in professional services”, Management Science, Vol. 54 No. 7, pp. 1231-1236.

Bratianu, C. and Leon, R.D. (2015), "Strategies to enhance intergenerational learning and reducing knowledge loss", VINE, Vol. 45 No. 4, pp. 551-567.

Bridoux, F., Smith, K.G. and Grimm, C.M. (2013), “The management of resources: Temporal effects of different types of actions on performance", Journal of Management, Vol. 39 No. 4, pp. 928-957.

Calo, T.J. (2008), "Talent management in the era of the aging workforce: The critical role of knowledge transfer", Public Personnel Management, Vol. 37 No. 4, pp. 403-416. 
Carlsson, S.A. (1991), "DSS and unlearning: Taking organizational environments into account", In Sol, H.G. and Vecsenyi, J. (Eds.), Environments for Supporting Decision Processes, North Holland, Amsterdam, pp. 371-385.

Carmona, S. and Gronlud, A. (1998), "Learning from forgetting. An experiential study of two European car manufacturers", Management Learning, Vol. 29 No. 1, pp. 21-38.

Carty, R. and Walsh, S. (2007), “The role of middle managers in knowledge transfer”, Journal of Information \& Knowledge Management, Vol. 6 No. 4, pp. 297-302.

Casey, A. (1997), “Collective memory in organizations”, Advances in Strategic Management, Vol. 14, pp. 111-146.

Casey, A. and Olivera, F. (2011), "Reflections on organizational memory and forgetting", Journal of Management Inquiry, Vol. 20 No. 3, pp. 305-310.

Casillas, J.C., Acedo, F.J. and Barbero, J.L. (2010), "Learning, unlearning and internationalisation: Evidence from the pre-export phase”, International Journal of Information Management, Vol. 30 No. 2, pp. 162-173.

Cattani, G., Dunbar, R.L.M. and Shapira, Z. (2012), "Value creation and knowledge loss: The case of Cremonese stringed instruments", Organization Science, Vol. 24 No. 2, pp. 813830.

Cegarra-Navarro, J.G. and Dewhurst, F.W. (2006), "Linking shared organizational context and relational capital through unlearning: An initial empirical investigation in SMEs", Learning Organization, Vol. 13 No. 1, pp. 49-62.

Cegarra-Navarro, J., Eldridge, S. and Sanchez, A.G. (2012), "How an unlearning context can help managers overcome the negative effects of counter-knowledge", Journal of Management and Organization, Vol. 18 No. 2, pp. 231-246.

Cirillo, B., Brusoni, S. and Valentini, G. (2014), “The rejuvenation of inventors through corporate spinouts", Organization Science, Vol. 25 No. 6, pp. 1764-1784. 
Ciuk, S. and Kostera, M. (2010), "Drinking from the waters of Lethe: A tale of organizational oblivion”, Management Learning, Vol. 41 No. 2, pp. 187-204.

Conti, R. (2014), “Do non-competition agreements lead firms to pursue risky R\&D projects?”, Strategic Management Journal, Vol. 35 No. 8, pp. 1230-1248.

Coopey, J. and Burgoyne, J. (2000), "Politics and organizational learning", Journal of Management Studies, Vol. 37 No. 6, pp. 869-885.

Cutcher, L., Dale, K. and Tyler, M. (2019), “'Remembering as forgetting’: Organizational commemoration as a politics of recognition”, Organization Studies, Vol. 40 No. 2, pp. 267-290.

Daghfous, A., Belkhodja, O. and Angell, L.C. (2013), "Understanding and managing knowledge loss", Journal of Knowledge Management, Vol. 17 No. 5, pp. 639-660.

Dalton, D.R., Krackhardt, D.M. and Porter, L.W. (1981), "Functional turnover: An empirical assessment”, Journal of Applied Psychology, Vol. 66 No. 6, pp. 715-721.

Daneke, G.A. (1985), "Regulation and the sociopathic firm”, Academy of Management Review, Vol. 10 No. 1, pp. 15-20.

Darr, E.D., Argote, L. and Epple, D. (1995), “The acquisition, transfer, and depreciation of knowledge in service organizations: Productivity in franchises”, Management Science, Vol. 41 No. 11, pp. 1750-1762.

David, G. and Brachet, T. (2011), "On the determinants of organizational forgetting”, American Economic Journal: Microeconomics, Vol. 3 No. 3, pp. 100-123.

Dewey, J. (1938), Education and Experience, Kappa Delta Pi, New York, NY.

Dreher, G.F. (1982), “The role of performance in the turnover process", Academy of Management Journal, Vol. 25 No. 1, pp. 137-147.

Droege, S.B. and Hoobler, J.M. (2003), "Employee turnover and tacit knowledge diffusion: A network perspective”, Journal of Managerial Issues, Vol. 15 No. 1, pp. 50-64. 
Easterby-Smith, M. and Lyles, M.A. (2011), "In praise of organizational forgetting”, Journal of Management Inquiry, Vol. 20 No. 3, pp. 311-316.

Eckardt, R., Skaggs, B.C. and Youndt, M. (2014), “Turnover and knowledge loss: An examination of the differential impact of production manager and worker turnover in service and manufacturing firms”, Journal of Management Studies, Vol. 51 No. 7, pp. 1025-1057.

Engeström, Y., Brown, K., Engeström, R. and Koistinen, K. (1990), “Organizational forgetting: An activity-theoretical perspective", in Middleton, D. and Edwards, D. (Eds.), Collective Remembering: Inquiries in Social Construction, Sage, Thousand Oaks, CA, pp. 139-168.

Epple, D., Argote, L. and Devadas, R. (1991), “Organizational learning curves: A method for investigating intra-plant transfer of knowledge acquired through learning by doing”, Organization Science, Vol. 2 No. 1, pp. 58-70.

Feldman, R.M. and Feldman, S.P. (2006), "What links the chain: An essay on organizational remembering as practice”, Organization, Vol. 13 No. 6, pp. 861-887.

Fernandez, V. and Sune, A. (2009), “Organizational forgetting and its causes: An empirical research", Journal of Organizational Change Management, Vol. 22 No. 6, pp. 620-634.

Fiol, M. and O’Connor, E. (2017a), “Unlearning established organizational routines_part I”, The Learning Organization, Vol. 24 No. 1, pp. 13-29.

Fiol, M. and O’Connor, E. (2017b), “Unlearning established organizational routines_part II”, The Learning Organization, Vol. 24 No. 2, pp. 82-92.

Foroughi, H. and Al-Amoudi, I. (2019), “Collecting forgetting in a changing organization: When memories become unusable and uprooted", Organization Studies. doi:0170840619830130. 
Gaur, A.S., Mukherjee, D., Gaur, S.S. and Schmid, F. (2011), "Environmental and firm level influences on inter-organizational trust and SME performance", Journal of Management Studies, Vol. 48 No. 1, pp. 1752-1781.

George, G., Haas, M.R. and Pentland, A. (2014), "Big data and management”, Academy of Management Journal, Vol. 57 No. 2, pp. 321-326.

Gutierrez, J.O., Cegarra-Navarro, J.G., Cepeda Carrion, G.A. and Leal Rodriguez, A.L. (2015), "Linking unlearning with quality of health services through knowledge corridors", Journal of Business Research, Vol. 68 No. 4, pp. 815-822.

Hatch, M.J. and Schultz, M. (2017), “Toward a theory of using history authentically: Historicizing in the Carlsberg Group”, Administrative Science Quarterly, Vol. 62 No. 4, pp. 657-697.

Haunschild, P. R., Polidoro, F. and Chandler, D. (2015), “Organizational oscillation between learning and forgetting: The dual role of serious errors", Organization Science, Vol. 26 No. 6, pp. 1682-1701.

Hedberg, B.L. (1981), “How organizations learn and unlearn”, in Nystrom, P.C. and Starbuck, W.H. (Eds.), Handbook of Organizational Design, Oxford University Press, New York, pp. 3-27.

Hedberg, B.L., Nystrom, P.C. and Starbuck, W.H. (1976), “Camping on seesaws: Prescriptions for a self-designing organization", Administrative Science Quarterly, Vol. 21 No. 1, pp. $41-65$.

Hirsch, W.Z. (1952), "Manufacturing progress functions”, Review of Economics and Statistics, Vol. 34 No. 2, pp. 143-155.

Howells, J. and Scholderer, J. (2016), "Forget unlearning? How an empirically unwarranted concept from psychology was imported to flourish in management and organization studies”, Management Learning, Vol. 47 No. 4, pp. 443-463. 
Huber, G.P. (1991), “Organizational learning: The contributing processes and the literatures”, Organization Science, Vol. 2 No. 1, pp. 88-115.

Ito, K. and Rose, E. (1994), “The genealogical structure of Japanese firms: Parent subsidiary relationships", Strategic Management Journal, Vol. 15 No. S2, pp. 35-51.

Jacovsky, E.F. (1984), “Turnover and job performance: An integrated process model”, Academy of Management Review, Vol. 9 No. 1, pp. 74-83.

Jafari, M., Rezaeenour, J., Mazdeh, M.M. and Hooshmandi, A. (2011), “Development and evaluation of a knowledge risk management model for project-based organizations: A multi-stage study", Management Decision, Vol. 49 No. 3, pp. 309-329.

Jennex, M. (2014), “A proposed method for assessing knowledge loss risk with departing personnel", VINE, Vol. 44 No. 2, pp. 185-209.

Joe, C., Yoong, P. and Patel, K. (2013), “Knowledge loss when older experts leave knowledgeintensive organizations”, Journal of Knowledge Management, Vol. 17 No. 6, pp. 913927.

Klammer, A., Grisold, T. and Gueldenberg, S. (2019), “Introducing a 'stop-doing-culture': How to free your organization from rigidity”, Business Horizons, Vol. 62 No. 4, pp. 451-458.

Klammer, A. and Gueldenberg, S. (2019a), "Unlearning and forgetting in organizations: A systematic review of literature", Journal of Knowledge Management, Vol. 23 No. 5, pp. 860-888.

Klammer, A. and Gueldenberg, S. (2019b), "Honor the old, welcome the new: An account of unlearning and forgetting in NPD teams", European Journal of Innovation Management, online ahead-of-print. doi:10.1108/EJIM-12-2018-0255.

Klein, J.I. (1989), "Parenthetic learning in organizations: Toward the unlearning of the unlearning model”, Journal of Management Studies, Vol. 26 No. 3, pp. 291-308. 
Kleiner, M.M., Nickelsburg, J. and Pilarski, A. (2012), “Organizational and individual learning and forgetting", Industrial and Labour Relations Review, Vol. 65 No. 1, pp. 68-80.

Kluge, A. and Gronau, N. (2018), "Intentional forgetting in organizations: The importance of eliminating retrieval cues for implementing new routines", Frontiers in Psychology, Vol. 9 Article 51.

Kluge, A., Schüffler, A., Thim, C., Haase, J. and Gronau, N. (2019), “Investigating unlearning and forgetting in organizations: Research methods, designs and implications", The Learning Organization, online ahead of print. doi:10.1108/TLO-09-2018-0146.

Lant, T.K., Milliken, F.J. and Batra, B. (1992), “The role of managerial learning and interpretation in strategic persistence and reorientation: An empirical exploration”, Strategic Management Journal, Vol. 13 No. 8, pp. 585-608.

Leal-Rodriguez, A.L., Eldridge, S., Roldan, J.L., Leal-Millan, A.G. and Ortega-Gutierrez, J. (2015), “Organizational unlearning, innovation outcomes, and performance: The moderating effect of firm size", Journal of Business Research, Vol. 68 No. 4, pp. 803809.

Lenehan, M. (1982), “The quality of the instrument”, The Atlantic Monthly, Vol. 250, pp. 32-58. Levallet, N. and Chan, Y. (2019), “Organizational knowledge retention and knowledge loss”, Journal of Knowledge Management, Vol. 23 No. 1, pp. 176-199.

Levy, M. (2011), “Knowledge retention: Minimizing organizational business loss”, Journal of Knowledge Management, Vol. 15 No. 4, pp. 582-600.

Lopez, L. and Sune, A. (2013), "Turnover-induced forgetting and its impact on productivity", British Journal of Management, Vol. 24 No. 1, pp. 38-53.

Lyles, M.A. and Thomas, H. (1988), "Strategic problem formulation: Bias and assumptions embedded in alternative decision-making models", Journal of Management Studies, Vol. 25 No. 2, pp. 131-145. 
Mariano, S. and Casey, A. (2013), “A dynamic model of knowledge shaping”, Proceedings of the Academy of Management Meeting, Lake Buena Vista (Orlando), FL, 9-13 August 2013, p. 14726.

Mariano, S. and Casey, A. (2016), "The dynamics of organizational routines in a startup: The EREDA model”, European Management Review, Vol. 13 No. 4, pp. 251-274.

Mariano, S., Casey, A. and Olivera, F. (2018), "Managers and organizational forgetting: A synthesis", The Learning Organization, Vol. 25 No. 3, pp. 169-179.

Markóczy, L. (1994), “Modes of organizational learning: Institutional change and Hungarian joint ventures", International Studies of Management \& Organization, Vol. 24 No. 4, pp. $5-30$.

Martin de Holan, P. (2011), “Agency in voluntary organizational forgetting”, Journal of Management Inquiry, Vol. 20 No. 3, pp. 317-322.

Martin de Holan, P. and Phillips, N. (2004a), "Organizational forgetting as strategy", Strategic Organization, Vol. 2 No. 4, pp. 423-433.

Martin de Holan, P. and Phillips, N. (2004b), "Remembrance of things past? The dynamics of organizational forgetting”, Management Science, Vol. 50 No. 11, pp. 1603-1613.

Martin de Holan, P., Phillips, N. and Lawrence, T. B. (2004), "Managing organizational forgetting”, MIT Sloan Management Review, Vol. 45 No. 2, pp. 45-51.

Massingham, P. (2008), "Measuring the impact of knowledge loss: More than ripples on a pond?", Management Learning, Vol. 39 No. 5, pp. 541-560.

Massingham, P. (2018), "Measuring the impact of knowledge loss: A longitudinal study", Journal of Knowledge Management, Vol. 22 No. 4, pp. 721-758.

McEvoy, G.M. and Cascio, W.F. (1987), "Do good or poor performers leave? A meta-analysis of the relationship between performance and turnover", Academy of Management Journal, Vol. 30 No. 4, pp. 744-762. 
Mena, S., Rintamaki, J., Fleming, P. and Spicer, A. (2015), "On the forgetting of corporate irresponsibility", Academy of Management Review, Vol. 41 No. 4, pp. 720-738.

Meschi, P. X. and Metais, E. (2013), “Do firms forget about their past acquisitions? Evidence from French acquisitions in the United States 1988-2006", Journal of Management, Vol. 39 No. 2, pp. 469-495.

Mezias, J., Grinyer, P. and Guth, W. (2001), “Changing collective cognition: A process model for strategic change", Long Range Planning, Vol. 34 No. 1, pp. 71-95.

Miles, M.B. and Huberman, A. M. (1994), Qualitative Data Analysis: A Sourcebook of New Methods, Sage, Newbury Park, CA.

Miller, K.D. and Martignoni, D. (2015), “Organizational learning with forgetting: Reconsidering the exploration-exploitation tradeoff", Strategic Organization, Vol. 14 No. 1, pp. 53-72.

Miller, K.D., Pentland, B.T. and Choi, S. (2012), "Dynamics of performing and remembering organizational routines”, Journal of Management Studies, Vol. 49 No. 8, pp. 1536-1558.

Morgenstern, J. (1997), “On film: The battle to save Star Wars”, The Wall Street Journal: A16.

Mowday, R.T., Porter, L.W. and Steers, R.M. (1982), Employee-Organization Linkages: The Psychology of Commitment, Absenteeism, and Turnover, Academic Press, New York, NY.

Nguyen, N. (2017), “The journey of organizational unlearning: A conversation with William H. Starbuck", The Learning Organization, Vol. 24 No. 1, pp. 58-66.

Norman, P.M. (2004), “Knowledge acquisition, knowledge loss, and satisfaction in high technology alliances", Journal of Business Research, Vol. 57 No. 6, pp. 610-619.

Nystrom, P.C. and Starbuck, W.H. (1984), “To avoid organizational crises, unlearn”, Organizational Dynamics, Vol. 12 No. 4, pp. 53-65.

Owen, W.F. (1984), "Interpretative themes in relational communication”, Quarterly Journal of Speech, Vol. 70 No. 3, pp. 274-287. 
Parise, S., Cross, R. and Davenport, T.H. (2006), "Strategies for preventing a knowledge-loss crisis”, MIT Sloan Management Review, Vol. 47 No. 4, pp. 31-39.

Pratt, M.G. and Barnett, C.K. (1997), “Emotions and unlearning in Amway recruiting techniques", Management Learning, Vol. 28 No. 1, pp. 65-88.

Price, J.L. (1977), The Study of Turnover, Iowa State University Press, Ames, IA.

Reitzig, M. and Wagner, S. (2010), “The hidden costs of outsourcing: Evidence from patent data”, Strategic Management Journal, Vol. 31 No. 11, pp. 1183-1201.

Salipante, P., Notz, W. and Bigelow, J. (1982), “A matrix approach to literature reviews”, in Staw, B.M. and Cummings, L.L. (Eds.), Research in Organizational Behavior, JAI Press, Greenwich, CT, pp. 321-348.

Scalzo, N.J. (2006), "Memory loss? Corporate knowledge and radical change", Journal of Business Strategy, Vol. 27 No. 4, pp. 60-69.

Schmitt, A., Borzillo, S. and Probst, G. (2011), “Don’t let knowledge walk away: Knowledge retention during employee downsizing”, Management Learning, Vol. 43 No. 1, pp. 5374.

Sharma, S. and Lenka, U. (2019), "Exploring linkages between unlearning and relearning in organizations", The Learning Organization, online ahead of print. doi:10.1108/TLO-102018-0164.

Shaw, J.D., Duffy, M.K., Johnson, J.L. and Lockhart, D.E. (2005), “Turnover, social capital losses, and performance”, Academy of Management Journal, Vol. 48 No. 4, pp. 594-606.

Sinkula, J.M. (2002), “Market-based success, organizational routines, and unlearning”, Journal of Business \& Industrial Marketing, Vol. 17 No. 4, pp. 253-269.

Smunt, T.L. (1987), “The impact of worker forgetting on production scheduling”, International Journal of Production Research, Vol. 25 No. 5, pp. 689-701. 
Starbuck, W.H. (1996), "Unlearning ineffective or obsolete technologies”, International Journal of Technology Management, Vol. 11 No. 7, pp. 725-737.

Strauss, A. and Corbin, J.M. (1998), Basics of Qualitative Research: Techniques and Procedures for Developing Grounded Theory, Sage, Newbury Park, CA.

Suddaby, R. (2010), "Construct clarity in theories of management and organization", Academy of Management Review, Vol. 35 No. 3, pp. 346-357.

Sule, D.R. (1983), "Effect of learning and forgetting on economic lot size”, International Journal of Production Research, Vol. 21 No. 5, pp. 771-786.

Sumbal, M.S., Tsui, E., Cheong, R. and See-to, E. (2018), “Critical areas of knowledge loss when employees leave in the oil and gas industry", Journal of Knowledge Management, Vol. 22 No. 7, pp. 1573-1590.

Tabassum Azmi, F. (2008), "Mapping the learn-unlearn-relearn model”, European Business Review, Vol. 20 No. 3, pp. 240-259.

Thompson, P. (2007), "How much did the Liberty shipbuilders forget?", Management Science, Vol. 53 No. 6, pp. 908-918.

Tranfield, D., Denyer, D. and Smart, P. (2003), “Towards a methodology for developing evidence-informed management knowledge by means of systematic review", British Journal of Management, Vol. 14 No. 3, pp. 207-222.

Treleaven, L. and Sykes, C. (2005), "Loss of organizational knowledge: From supporting clients to serving head office”, Journal of Organizational Change Management, Vol. 18 No. 4, pp. 353-368.

Tripsas, M. and Gavetti, G. (2000), “Capabilities, cognition, and inertia: Evidence from digital imaging”, Strategic Management Journal, Vol. 21 No. 10-11, pp. 1147-1161.

Tsang, E.W.K. (2008), “Transferring knowledge to acquisition joint ventures: An organizational unlearning perspective", Management Learning, Vol. 39 No. 1, pp. 5-20. 
Tsang, E.W.K. (2017), "How the concept of organizational unlearning contributes to studies of learning organizations: A personal reflection”, The Learning Organization, Vol. 24 No. 1, pp. 39-48.

Tsang, E.W.K. and Zahra, S.A. (2008), “Organizational unlearning”, Human Relations, Vol. 61 No. 10, pp. 1435-1462.

Volland, M. (2019), "How to intentionally forget rules in newly introduced agile projects", The Learning Organization, online ahead of print. doi:10.1108/TLO-10-2018-0165.

Ward, S. and Wooler, I. (2010), "Keeping knowledge flowing in a downturn: Actions for knowledge and information managers", Business Information Review, Vol. 27 No. 4, pp. $253-262$.

Webster, J. and Watson, R.T. (2002), “Analyzing the past to prepare the future: Writing a literature review", MIS Quarterly, Vol. 26 No. 2, pp. xiii-xxiii.

Wells, D.L. and Muchinsky, P.M. (1985), "Performance antecedents of voluntary and involuntary managerial turnover”, Journal of Applied Psychology, Vol. 70 No. 2, pp. 329-336.

Wong, P.S.P., Cheung, S.O., Yiu, R.L.Y. and Hardie, M. (2012), "The unlearning dimension of organizational learning in construction projects", International Journal of Project Management, Vol. 30 No. 1, pp. 94-104.

Yildiz, H.E. and Fey, C.F. (2010), “Compatibility and unlearning in knowledge transfer in mergers and acquisitions", Scandinavian Journal of Management, Vol. 26 No. 4, pp. 448456.

Younge, K.A., Tong, T.W. and Fleming, L. (2015), "How anticipated employee mobility affects acquisition likelihood: Evidence from a natural experiment”, Strategic Management Journal, Vol. 36 No. 5, pp. 686-708. 
Zahra, S.A., Abdelgawad, S.G. and Tsang, E.W.K. (2011), "Emerging multinationals venturing into developed economies: Implications for learning, unlearning, and entrepreneurial capability", Journal of Management Inquiry, Vol. 20 No. 6, pp. 323-330.

Zhao, Y., Lu, Y. and Wang, X. (2013), “Organizational unlearning and organizational relearning: A dynamic process of knowledge management", Journal of Knowledge Management, Vol. 17 No. 6, pp. 902-912. 
TABLE 1

Systematic Literature Review: Planning, Organizing and Reporting*

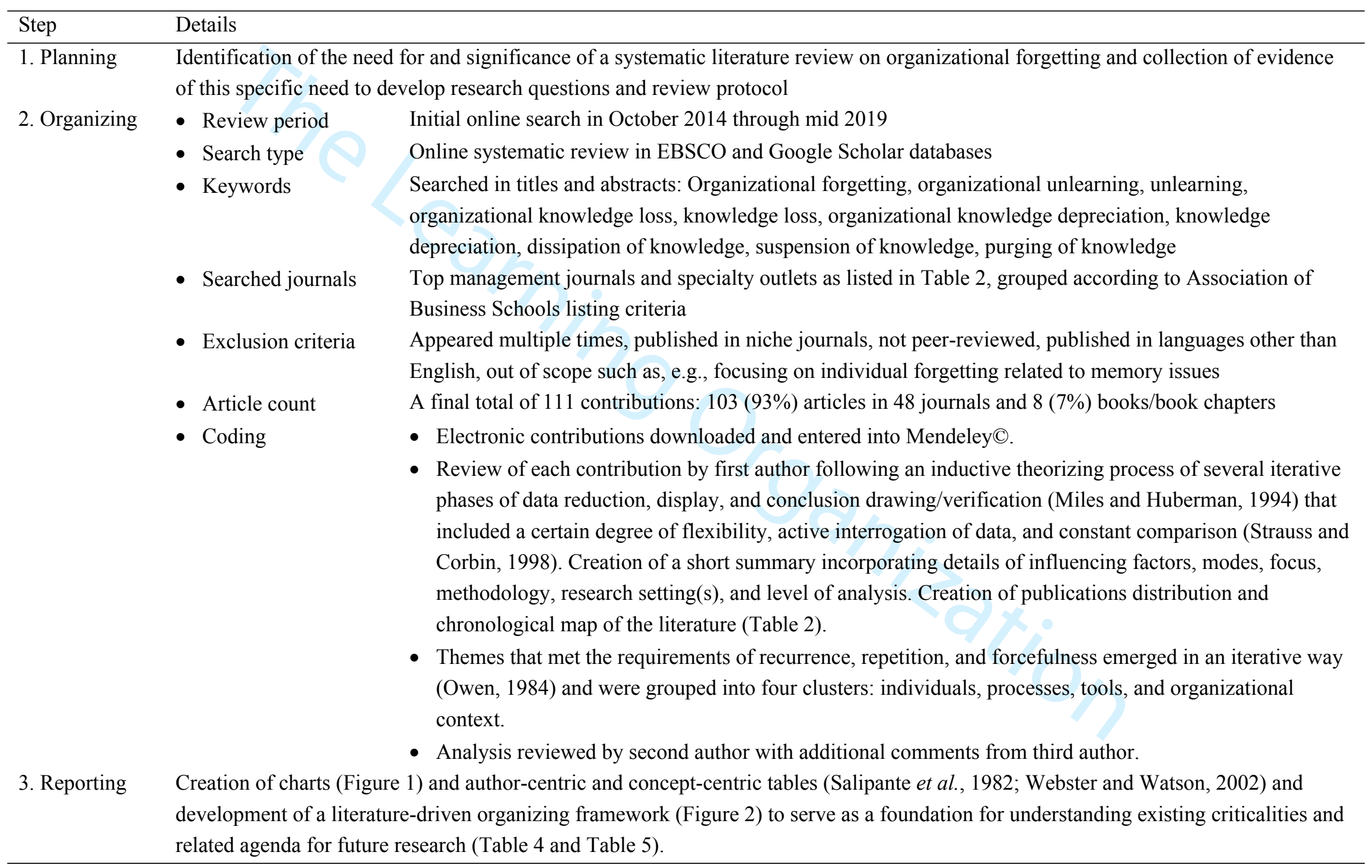


*Based on Tranfield et al. (2003), Webster and Watson (2002).

\section{TABLE 2}

List of Journals, Article Count, Author(s), and Related Focus

\begin{tabular}{|c|c|c|c|}
\hline $\begin{array}{c}\text { Journal title } \\
(\mathrm{N}=48)\end{array}$ & $\begin{array}{l}\text { Article count } \\
(\mathrm{N}=111)\end{array}$ & Author(s) & Focus** \\
\hline Economics, Econometrics, and Statistics & $3,3 \%$ & & \\
\hline American Economic Journal & 1 & David and Brachet (2011) & $\mathrm{KD}$ \\
\hline American Economic Review & 1 & Benkard (2000) & $\mathrm{KD}$ \\
\hline Review of Economics and Statistics & 1 & Hirsch (1952) & $\mathrm{KD}$ \\
\hline General Management, Ethics and Social Responsi & $30,26 \%$ & & \\
\hline Academy of Management Journal & 3 & $\begin{array}{l}\text { Barkema and Vermeulen (1998); Barker et al. (2001); Shaw et al. } \\
(2005)\end{array}$ & $\mathrm{U}, \mathrm{U}, \mathrm{KL}$ \\
\hline Academy of Management Review & 2 & Daneke (1985); Mena et al. (2015) & $\mathrm{U}, \mathrm{U}$ \\
\hline Administrative Science Quarterly & 2 & Hedberg et al. (1976); Hatch and Schultz (2017) & $\mathrm{U}, \mathrm{U}$ \\
\hline British Journal of Management & 1 & Lopez and Sune (2013) & KD \\
\hline Business Horizons & 1 & Klammer et al. (2019) & $\mathrm{U}$ \\
\hline European Business Review & 1 & Tabassum Azmi (2008) & $\mathrm{U}$ \\
\hline European Management Review & 1 & Mariano and Casey (2016) & $\mathrm{KL}$ \\
\hline Journal of Business Research & 3 & Norman (2004); Gutierrez et al. (2015); Leal-Rodriguez et al. (2015) & $\mathrm{KL}, \mathrm{U}, \mathrm{U}$ \\
\hline Journal of Management & 1 & Meschi and Metais (2013) & $\mathrm{KD}$ \\
\hline Journal of Management Inquiry & 6 & $\begin{array}{l}\text { Droege and Hoobler (2003); Easterby-Smith and Lyles (2011); } \\
\text { Martin de Holan (2011); Casey and Olivera (2011); Zahra et al. } \\
\text { (2011); Antonacopoulou and Sheaffer (2013) }\end{array}$ & $\begin{array}{l}\mathrm{KL}, \mathrm{KL} \\
\mathrm{U}, \mathrm{KL} \\
\mathrm{U}, \mathrm{U}\end{array}$ \\
\hline Journal of Management Studies & 5 & $\begin{array}{l}\text { Lyles and Thomas (1988); Klein (1989); Coopey and Burgoyne } \\
\text { (2000); Gaur et al. (2011); Eckardt et al. (2014) }\end{array}$ & $\begin{array}{l}\mathrm{U}, \mathrm{U}, \mathrm{U} \\
\mathrm{U}, \mathrm{KL}\end{array}$ \\
\hline Management Decision & 1 & Jafari et al. (2011) & KL \\
\hline MIT-Sloan Management Review & 2 & Martin de Holan et al. (2004); Parise et al. (2006) & $\mathrm{KL}, \mathrm{KL}$ \\
\hline Scandinavian Journal of Management & 1 & Yildiz and Fey (2010) & $\mathrm{U}$ \\
\hline $\begin{array}{l}\text { Human Resource Management and Employment } \\
\text { Studies }\end{array}$ & $2,2 \%$ & & \\
\hline Industrial and Labor Relations Review & 1 & Kleiner et al. (2012) & $\mathrm{KD}$ \\
\hline Frontiers in Psychology* & 1 & Kluge and Gronau (2018) & $\mathrm{KL}$ \\
\hline Information Management & $2,2 \%$ & & \\
\hline International Journal of Information Management & 1 & Casillas et al. (2010) & $\mathrm{U}$ \\
\hline International Journal of Project Management & 1 & Wong et al. (2012) & $\mathrm{U}$ \\
\hline
\end{tabular}




\begin{tabular}{l}
\hline \multicolumn{1}{c}{$\begin{array}{c}\text { Journal title } \\
(\mathbf{N = 4 8 )}\end{array}$} \\
\hline Innovation \\
European Journal of Innovation Management \\
Journal of Product Innovation Management \\
Public Personnel Management* \\
Management Development and Education \\
Management Learning
\end{tabular}

\section{Marketing}

Journal of Business and Industrial Marketing

\section{Operation Research and Management Science}

IEEE Transactions on Engineering Management International Journal of Production Research

Management Science

\section{Operation and Technology Management}

International Journal of Technology Management*

Manufacturing and Service Operations Management

\section{Organization Studies}

Business Information Review*

Human Relations

International Studies of Management \& Organization* Journal of Information and Knowledge Management* Journal of Knowledge Management

\section{Journal of Organizational Change Management} Organization

Organization Science

\begin{tabular}{|c|c|c|}
\hline $\begin{array}{l}\text { Article count } \\
(\mathrm{N}=111)\end{array}$ & Author(s) & Focus** \\
\hline \multicolumn{3}{|l|}{$3,3 \%$} \\
\hline 1 & Klammer and Gueldenberg (2019b) & $\mathrm{KL}+\mathrm{U}$ \\
\hline 1 & Akgün et al. (2007) & $\mathrm{U}$ \\
\hline 1 & Calo (2008) & $\mathrm{U}$ \\
\hline \multicolumn{3}{|l|}{$7,6 \%$} \\
\hline 7 & $\begin{array}{l}\text { Pratt and Barnett (1997); Carmona and Gronlud (1998); Massingham } \\
\text { (2008); Tsang (2008); Ciuk and Kostera (2010); Schmitt et al. } \\
\text { (2011); Howells and Scholderer (2016) }\end{array}$ & $\begin{array}{l}\mathrm{U}, \mathrm{KL}, \\
\mathrm{KL}, \mathrm{U}, \\
\mathrm{KL}, \mathrm{KL}, \\
\mathrm{U}\end{array}$ \\
\hline \multicolumn{3}{|l|}{$1,1 \%$} \\
\hline 1 & Sinkula (2002) & $\mathrm{U}$ \\
\hline \multicolumn{3}{|l|}{$9,8 \%$} \\
\hline 1 & Baloff (1970) & KD \\
\hline 2 & Sule (1983); Smunt (1987) & $\mathrm{KD}, \mathrm{KD}$ \\
\hline 6 & $\begin{array}{l}\text { Bailey (1989); Argote } \text { et al. (1990); Darr et al. (1995); Martin de } \\
\text { Holan and Phillips (2004b); Thompson (2007); Boone } \text { et al. (2008) }\end{array}$ & $\begin{array}{l}\mathrm{KD}, \mathrm{KD} \\
\mathrm{KD}, \mathrm{KL}\end{array}$ \\
\hline \multicolumn{2}{|l|}{$2,2 \%$} & $\mathrm{KD}, \mathrm{KD}$ \\
\hline 1 & Starbuck (1996) & $\mathrm{U}$ \\
\hline 1 & Agrawal and Muthulingam (2015) & $\mathrm{KD}$ \\
\hline \multicolumn{3}{|l|}{$34,31 \%$} \\
\hline 1 & Ward and Wooler (2010) & KL \\
\hline 1 & Tsang and Zahra (2008) & $\mathrm{U}$ \\
\hline 1 & Markóczy (1994) & $\mathrm{U}$ \\
\hline 1 & Carty and Walsh (2007) & $\mathrm{KL}$ \\
\hline 8 & $\begin{array}{l}\text { Levy (2011); Daghfous et al. (2013); Joe et al. (2013); Zhao et al. } \\
\text { (2013); Massingham (2018); Sumbal et al. (2018); Klammer and } \\
\text { Gueldenberg (2019a); Levallet and Chan (2019) }\end{array}$ & $\begin{array}{l}\text { KL, KL, } \\
\text { KL, U, } \\
\text { KL, KL, } \\
\text { U, KL }\end{array}$ \\
\hline 2 & Treleaven and Sykes (2005); Fernandez and Sune (2009) & KL, KL \\
\hline 1 & Feldman and Feldman (2006) & KL \\
\hline 5 & $\begin{array}{l}\text { Epple et al. (1991); Anand et al. (2012); Cattani et al. (2012); Cirillo } \\
\text { et al. (2014); Haunschild et al. (2015) }\end{array}$ & $\begin{array}{l}\mathrm{KD}, \mathrm{KD} \\
\mathrm{KL}, \mathrm{U} \\
\mathrm{KL}\end{array}$ \\
\hline
\end{tabular}




\begin{tabular}{|c|c|c|c|}
\hline $\begin{array}{c}\text { Journal title } \\
(\mathbf{N}=48)\end{array}$ & $\begin{array}{c}\text { Article count } \\
(\mathrm{N}=111)\end{array}$ & Author(s) & Focus** \\
\hline Organization Studies & 2 & Cutcher et al. (2019); Foroughi and Al-Amoudi (2019) & $\mathrm{U}, \mathrm{KL}$ \\
\hline Organizational Dynamics & 1 & Nystrom and Starbuck (1984) & $\mathrm{U}$ \\
\hline The Learning Organization & 9 & $\begin{array}{l}\text { Fiol and O'Connor (2017a, 2017b); Tsang (2017); Mariano et al. } \\
\text { (2018), Becker (2018b, 2019); Kluge et al. (2019); Sharma and } \\
\text { Lenka (2019); Volland (2019) }\end{array}$ & $\begin{array}{l}\mathrm{U}, \mathrm{U}, \mathrm{U} \\
\mathrm{KL}+\mathrm{U} \\
\mathrm{U}, \mathrm{U}, \mathrm{U} \\
\mathrm{U}, \mathrm{U}\end{array}$ \\
\hline VINE* & 2 & Jennex (2014); Bratianu and Leon (2015) & $\mathrm{KL}, \mathrm{KL}$ \\
\hline Strategy & $10,9 \%$ & & \\
\hline Journal of Business Strategy* & 1 & Scalzo (2006) & KL \\
\hline Journal of Management and Organization* & 1 & Cegarra-Navarro et al. (2012) & $\mathrm{U}$ \\
\hline Long Range Planning & 1 & Mezias et al. (2001) & $\mathrm{U}$ \\
\hline Strategic Management Journal & 5 & $\begin{array}{l}\text { Reitzig and Wagner (2010); Conti (2014); Younge et al. (2015); Lant } \\
\text { et al. (1992); Ito and Rose (1994) }\end{array}$ & $\begin{array}{l}\mathrm{KL}, \mathrm{KL} \\
\mathrm{KL}, \mathrm{U}, \mathrm{U}\end{array}$ \\
\hline Strategic Organization & & Martin de Holan and Phillips (2004a); Miller and Martignoni (2015) & $\mathrm{KL}, \mathrm{KL}$ \\
\hline Book/Book Chapters & $8,7 \%$ & $\begin{array}{l}\text { Dewey (1938); Hedberg (1981); Engeström et al. (1990); Huber } \\
\text { (1991); Carlsson (1991); Blackler et al. (1999); Argote (2013); } \\
\text { Becker (2018a) }\end{array}$ & $\begin{array}{l}\mathrm{U}, \mathrm{U}, \\
\mathrm{KL}, \mathrm{U} \\
\mathrm{U}, \mathrm{KL} \\
\mathrm{KD} \\
\mathrm{KL}+\mathrm{U}\end{array}$ \\
\hline
\end{tabular}

${ }^{*}$ Not listed in Association of Business Schools listing. ${ }^{* *} \mathrm{KD}=$ knowledge depreciation; $\mathrm{KL}=$ knowledge loss; $\mathrm{U}=$ unlearning. 
Mapping the Literature

\begin{tabular}{|c|c|c|c|c|c|c|}
\hline \multirow{2}{*}{ Modes } & \multirow{2}{*}{ Foci } & \multirow{2}{*}{ Decade } & \multicolumn{2}{|c|}{ Key contributions } & \multirow{2}{*}{ Key insights } & \multirow{2}{*}{$\begin{array}{c}\text { Influencing } \\
\text { factors }\end{array}$} \\
\hline & & & Conceptual & Empirical & & \\
\hline \multirow[t]{7}{*}{ Accidental } & $\begin{array}{l}\text { Knowledge } \\
\text { depreciation }\end{array}$ & 1950 & & Hirsch (1952) & $\begin{array}{l}\text { A first article published in the economics literature } \\
\text { discusses how production interruptions have a negative } \\
\text { effect on learning curves in the manufacturing industry. } \\
\text { It proposes that lot size and frequency of production } \\
\text { influence knowledge depreciation. }\end{array}$ & $\begin{array}{l}\text { Processes: } \\
\text { Production } \\
\text { mechanisms }\end{array}$ \\
\hline & & 1970 & & Baloff (1970) & $\begin{array}{l}\text { The focus remains on manufacturing with an article on } \\
\text { deviancies from expected productivity patterns that } \\
\text { result in productivity depreciation. }\end{array}$ & $\begin{array}{l}\text { Processes: } \\
\text { Production } \\
\text { mechanisms }\end{array}$ \\
\hline & & 1980 & & $\begin{array}{l}\text { Sule (1983); } \\
\text { Bailey (1989); } \\
\text { Smunt (1987) }\end{array}$ & $\begin{array}{l}\text { During this decade, manufacturing studies continue to } \\
\text { emphasize the influence of production phases on } \\
\text { depreciation (Smunt, 1987; Sule, 1983). A study } \\
\text { proposes that amount learned and passage of time } \\
\text { explain depreciation (Bailey, 1989). }\end{array}$ & $\begin{array}{l}\text { Processes: } \\
\text { Production } \\
\text { mechanisms }\end{array}$ \\
\hline & & 1990 & & $\begin{array}{l}\text { Argote et al. } \\
\text { (1990); Epple et }\end{array}$ & $\begin{array}{l}\text { Argote et al. (1990) and Epple et al. (1991) continue to } \\
\text { focus on manufacturing, while Darr et al. (1995) }\end{array}$ & $\begin{array}{l}\text { Individuals: } \\
\text { Turnover }\end{array}$ \\
\hline & & & & $\begin{array}{l}\text { al. (1991); Darr } \\
\text { et al. (1995) }\end{array}$ & $\begin{array}{l}\text { conduct preliminary investigations in the service } \\
\text { industry. Contrasting findings emerge on whether } \\
\text { turnover influences depreciation. First hypotheses }\end{array}$ & $\begin{array}{l}\text { Processes: } \\
\text { Production } \\
\text { mechanisms }\end{array}$ \\
\hline & & & & & $\begin{array}{l}\text { suggest that organizations with skilled workers are } \\
\text { more affected by depreciation in the presence of high } \\
\text { turnover rates and that organizations with a lower level } \\
\text { of technology could be affected by depreciation more } \\
\text { than technologically sophisticated organizations. }\end{array}$ & $\begin{array}{l}\text { Tools: } \\
\text { Physical and } \\
\text { electronic } \\
\text { repositories }\end{array}$ \\
\hline & & 2000 & & $\begin{array}{l}\text { Benkard } \\
\text { (2000); } \\
\text { Thompson } \\
\text { (2007); Boone } \\
\text { et al. (2008) }\end{array}$ & $\begin{array}{l}\text { Turnover continues to be examined in aircraft } \\
\text { production (Benkard, 2000), shipbuilding (Thompson, } \\
\text { 2007), or in the service industry (Boone et al., 2008) } \\
\text { but contrasting findings still remain. }\end{array}$ & $\begin{array}{l}\text { Individuals: } \\
\text { Turnover }\end{array}$ \\
\hline
\end{tabular}




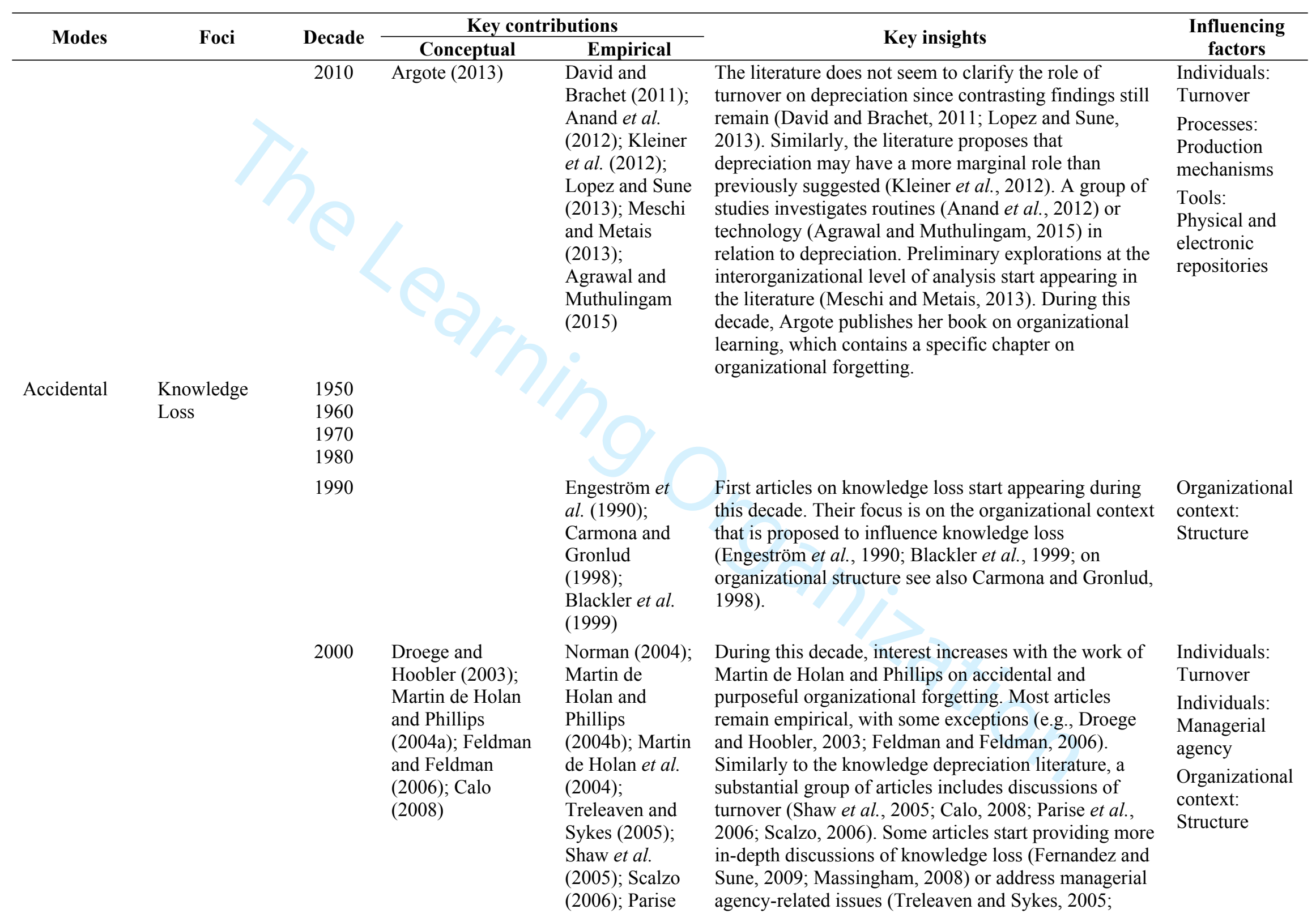




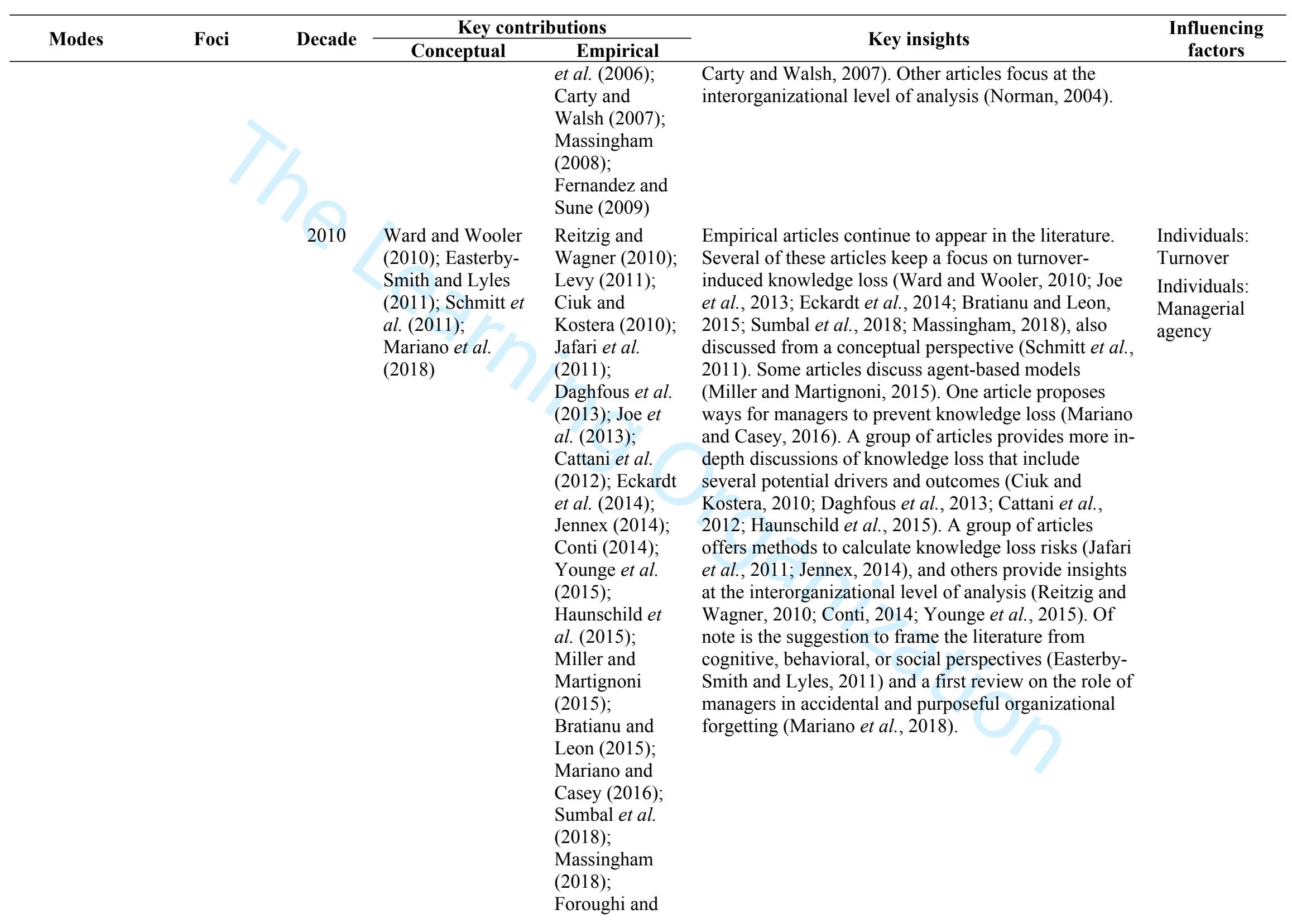




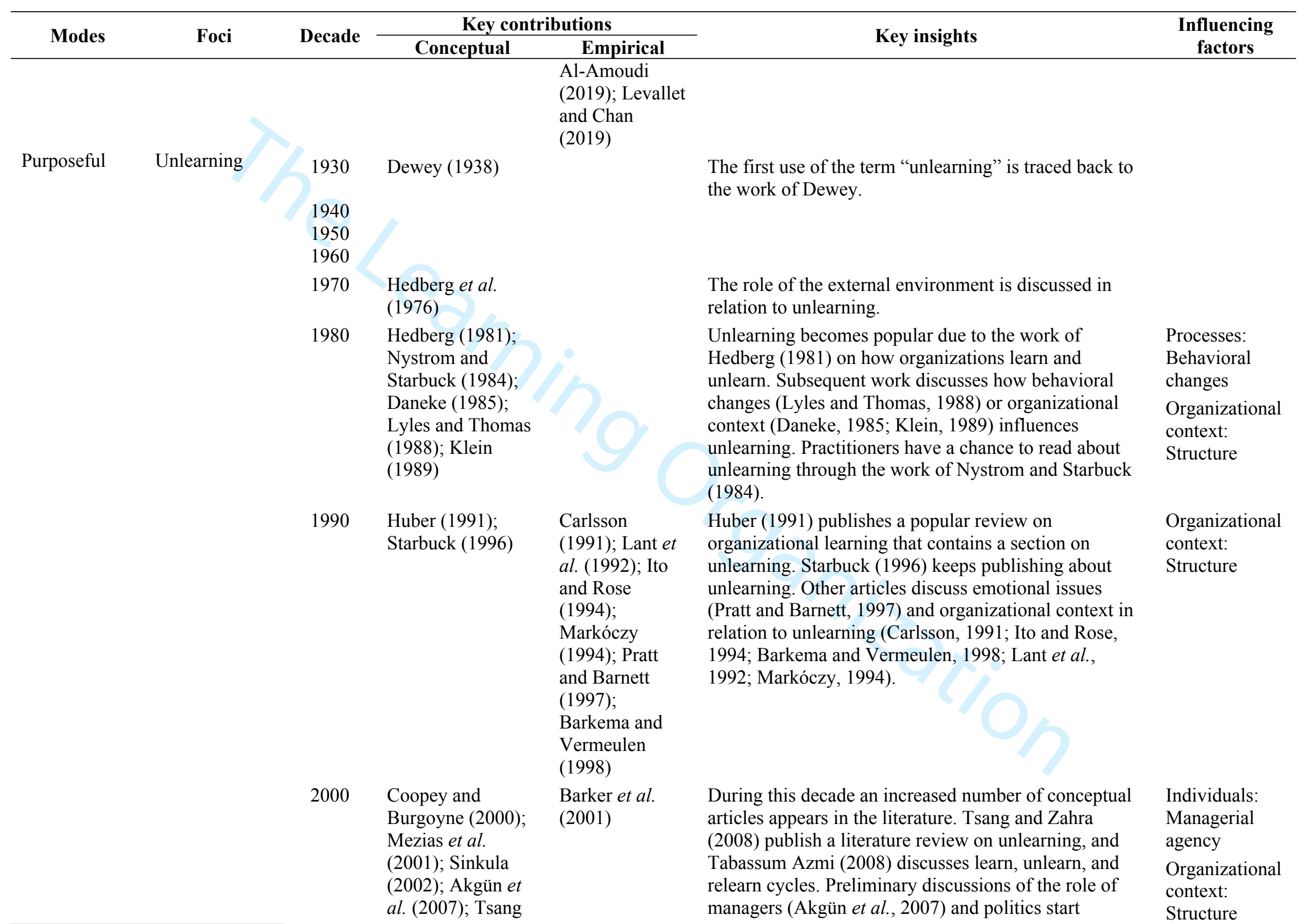




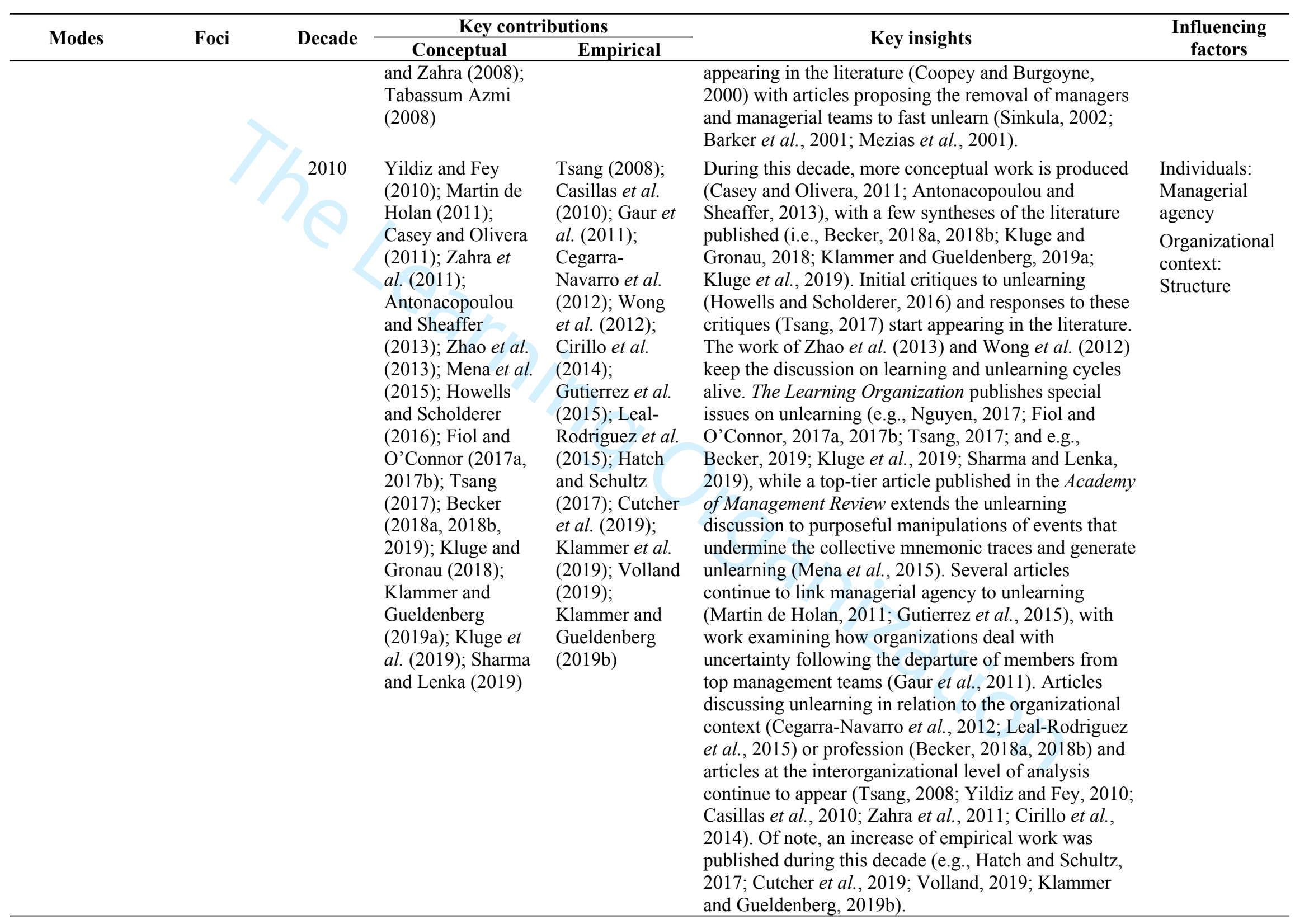


FIGURE 1. Publications Distribution
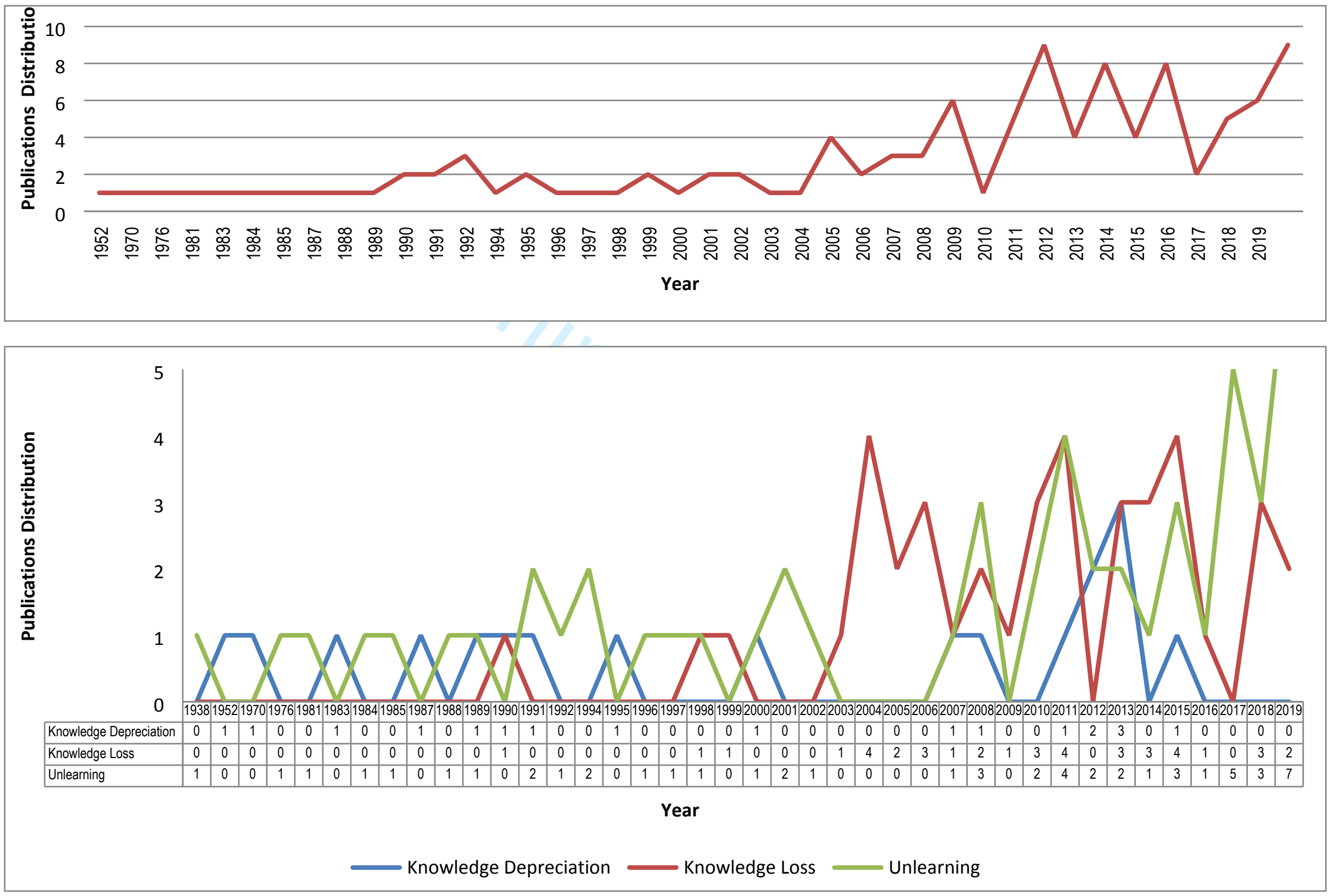
ORGANIZATIONAL FORGETTING

Organizing Framework of Current Organizational Forgetting Literature

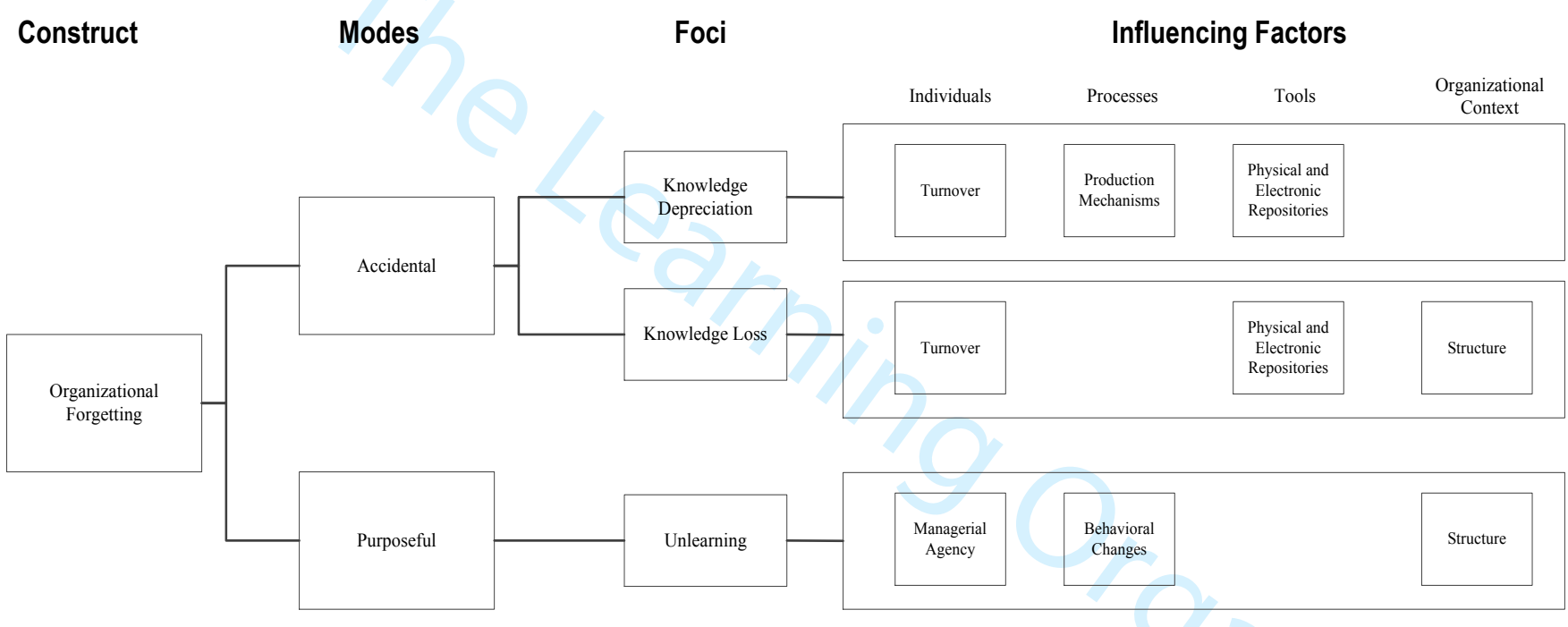

